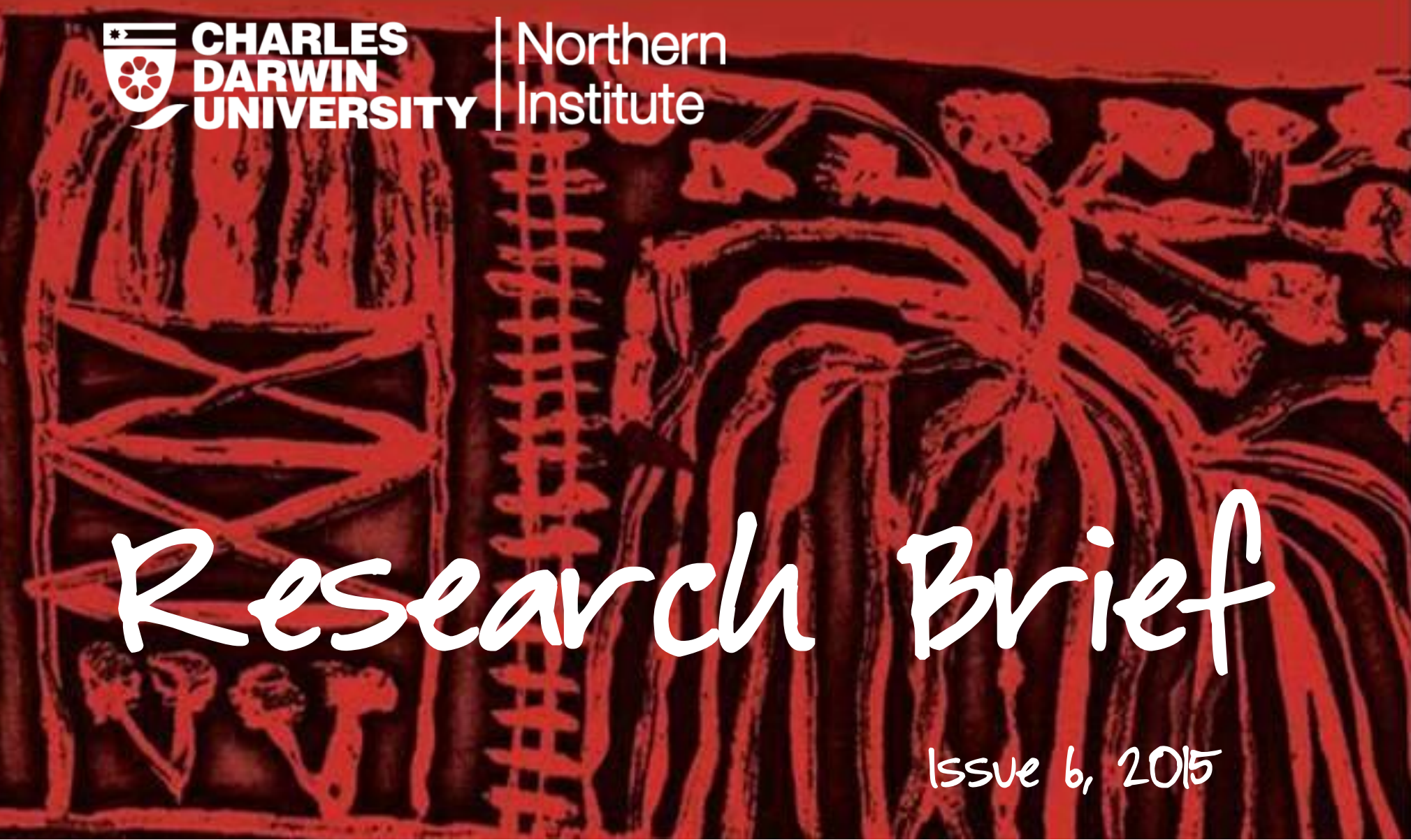

\title{
The Demography of Developing Northern Australia
}

Andrew Taylor

Hannah Payer

Huw Brokensha

Demography and Growth Planning, Northern Institute

andrew.taylor@cdu.edu.au 


\section{CHABLES Northern

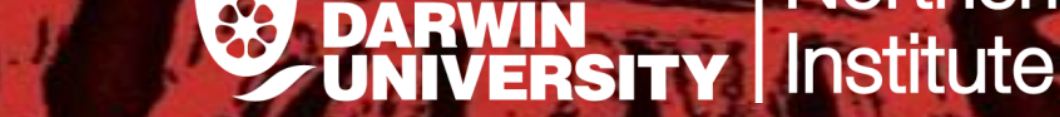

\section{RESEARCH AIM}

In this brief we analyse data and make commentary on the population related aspirations inherent in the Developing Northern Australia White and Green Papers. The aim is to identify the opportunities and challenges based on the pre-existing population and to comment on the population targets and desired changes which can be distilled from the Australian Government's agenda in relation to developing northern Australia.

\section{KEY FINDINGS}

- Our analysis of the population aspirations in the White Paper on Developing Northern Australia of developing several cities of more than one million residents and a total population of between four and five million people by the year 2060, suggests these are unlikely (with the estimated population of the region in 2014 at around 1.3 million residents).

- The Green Paper identified more sophisticated and important population aspirations which can be distilled as:

1. Significantly growing the populations of urban zones in the north

2. Improving net interstate migration flows between the north and remainder of Australia

3. Increase international migration to the region

- Population growth in northern Australia is focused towards the larger urban centres and these are home to an increasing proportion of the region's Indigenous and non-Indigenous population

- Net migration flows for the region are male biased, particularly for overseas migrants. The region fares poorly in retaining women in their late teens and early 20 s as well as in pre and post retirement years.

- Consequently, there is a strong and growing male bias across age groups and redressing this is critical to securing growth based on internally sourced capital and labour. To date, northern Australia is increasingly dependent on externally sourced capital and labour.

- The dual issues of forthcoming population ageing and large declines in the region's share of the national Indigenous population, represent major challenges to the region's financial capacity to support existing residents who may not be engaged in the labour force. These include the most vulnerable and marginalised residents who may become part of a growing class of residents with relatively poor socio economic status and who do not have the means to leave the region.

- Our research highlights the diversity of economies and populations within the region making it imperative that rollout of White Paper initiatives is accompanied by contextualized research on population scenarios (especially projections) under a range of development outcomes. 


\section{OCHARIES Northern

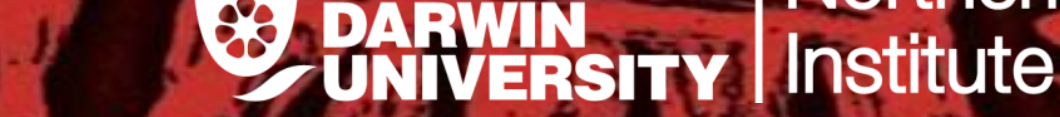

\section{Background}

The present-day focus on developing northern Australia emanates from a pre-2014 election commitment by the now incumbent Abbott Government - the 2030 Vision for Developing Northern Australia (Liberal Party of Australia, 2014). The policy's central element was to deliver a white paper outlining the Australian Government's strategies in relation to northern development. In the Australian political context, white papers are official and national level elucidations of policy platforms on specific macro-level issues which are considered to be strategically important. In the past there have been white papers in areas such as national defence, education and engagement with Asia.

The white paper process in Australia signifies a policy position for the Australian Government, initially articulated in the form of a green paper, against which public consultations and submissions are tabled before a white paper is produced. As the starting point for the developing northern Australia agenda, the Green Paper for Developing Northern Australia incorporated some relatively detailed population related aspirations. To articulate the issues obtained in feedback on the Green Paper, a Joint Select Committee on Developing Northern Australia was established. The terms of reference for the Committee, which consisted of parliamentary representatives from across political parties, can be summarised as:

- Assessing the potential for the expansion of key industries of minerals, energy, agriculture, tourism and defence;

- Recommending to government ways to enhance trade and investment with the Asia-Pacific region, address barriers to growth and establish conditions for investment and innovation

- Identifying vital infrastructure to support long term growth; and

- Outlining actions (for inclusion in the White Paper) to be taken by government to implement the committee's recommendations, including how these might be financed.

The Committee delivered its final report in late 2014 titled Pivot North - Inquiry into the Development of Northern Australia (Australian Government, 2014b). It identified the small population of northern Australia as the '...key impediment to be overcome.' (Australian Government, 2014b, p. 109). This is in line with past iterations surrounding northern development, within which the goal of significantly growing the population size of northern Australia has been promulgated as vital to facilitating economic growth (Carson, 2011b).

In this brief we distil the main population themes which are evident in the Green and White Papers, examine demographic nuances around these, and analyse population data to comment on the opportunities and challenges inherent in the aspirations raised in relation to population change and economic growth. 


\section{Northern Institute}

\section{North Australian population aspirations}

The perceived significance of securing substantial growth in the resident population size for northern Australia is evident in the Green Paper, the final report from the Joint Standing Committee and also in the White Paper which was released in June 2015 (Australian Government, 2015). Similar to past reports and inquiries (for example, Coombs, 1947; Harris, 1992), a bigger population in the north is seen as vital, but supporting details about what this might mean in terms of the relationships of population size and demographic change to development are scant. This might partly reflect 'misbehaviours' in such relationships observed in northern developed regions (Carson et al., 2011). For example, during 2015, the economy of the Northern Territory was purportedly booming (with record low unemployment and record high private investment) at the same time as record numbers of residents were leaving for interstate; some 26,000 in eighteen months, or the equivalent to its second largest city of Alice Springs (see Payer and Taylor, 2015). This highlights associations between population size and economic growth are not linear in northern economies, as they tend to be in the larger urban focused southern economies (see Carson et al., 2011; Carson 2011b).

The concentration on absolute growth in the size of the population which is evident and implicit within several iterations of reviews, parliamentary enquiries and other investigations on northern Australian development is also made explicit in the present day Green and White Papers. Likewise, past reviews and policies have identified population growth as imperative, along with consistent messaging about retaining residents in the north, in itself implicit recognition of the social and economic issues associated with the high rates of population turnover observed in most northern peripheries (Carson, 2011b).

This focus on size may reflect a relatively poor understanding within governments and industry about the complexities and diversity of northern population systems. Theories on 'what matters up north' for the causes and consequences of population change have begun to emerge from international cross-comparative studies relating to northern parts of developed nations. One theory (Carson et al., 2011) has proposed the systems of human interaction (demography, economics, social systems, health systems etc.) are different in sparsely populated areas such as northern Australia in comparison to urban or rural zones. The differences can be conveniently described using eight words that start with ' $D$ ' - detailed, diverse, discontinuous, dynamic, dependent, delicate, distant, and disconnected. The tenet is northern peripheral populations do not 'behave' like others, and demographic change can and does occur along non-standard pathways in comparison to other parts with the spatial nature of change largely unrelated.

While the Green Paper has articulated a range of population aspirations, the White Paper is less detailed, with the focus firmly on growing the absolute population size. The latter features the dual targets of growing several cities to a size of more than one million residents (page 3 ) and growing the region to between four to five million residents by the year 2060 (page 4). While the Green Paper focused on the need for strong population growth as well, important demographic pre-conditions to be found in northern Australia were also articulated, including highlighting how these were different to southern regions. They included a high concentration of the population in 


\section{CHABLES Northern UTISITY/ Institute}

urban areas (particularly in Darwin, Cairns and Townsville), great diversity and polarity in the demographic and socio-economic characteristics of settlements and their residents (particularly between urban and other areas as well as Indigenous and other residents), disparate population growth rates between urban and other areas, and the prevalence of a large number of small and very remote settlements away from coastal zones (Australian Government, 2014a).

Importantly, three key population-related ambitions upon which economic development, diversification and sustainment in the region might be based can be distilled from the Green Paper:

1. A focus on substantially growing 'urban zones': “...the White Paper will consider options for building on existing key urban zones - such as Darwin, Cairns, Townsville and Karratha with the aim of substantially increasing their population." (p. 54)

2. Improve net internal migration flows: "Greater migration from elsewhere in Australia would help boost population... The White Paper will explore practical options to remove some of the impediments to internal migration to northern Australia - recognising governments have limited ability to directly affect people's decisions as to where they live and work." (p. 54)

3. Increase international migration: "...the Australian Government is consulting across governments, industry, business and communities on ways migration policy can help increase the availability of skilled and unskilled labour, including in the north." (p. 56) (Adapted by the author from: Australian Government, 2014a)

These aspirations, along with re-enforcement of the paradigm of 'big is best' in the White Paper in the form of specific population targets, raise many questions about why and how such goals might be imperative. Not least are questions around environmental damage and sustainability with the large proposed population increases (of around four fold). A further important question concerns the characteristics of the future northern population and in particular, the characterisitics which might be considered as desirable (in terms of age, gender, skills, education and so on) in difference to pre-existing resident characteristics? These issues have received little commentary in the Green or White Papers, aside from discussions on the need to attract and retain skilled migrants.

Analysis on the issue of the population composition required for future development of northern Australia and how it might differ from the existing population has to date been disparate. There is no research-based review available, for example, on the critical issue of who comes, who leaves and who stays in the region. Such knowledge is vital in the context of opportunities and barriers for growing the population and achieving the ambitions embedded in the Green Paper. In addition, knowledge of these issues may be important for projecting what might eventuate in terms of population size, composition and distribution for the region in the short to medium future. There is also a lack of discourse on what the ongoing male dominance in the population represents, and how this may be impinging on economic and social progress. Consequently, the aim in this brief is to examine key demographic and socio-economic characteristics of the existing northern Australia population in order to comment on the influence these may have on 


\section{$\because$ CHARLES Northern

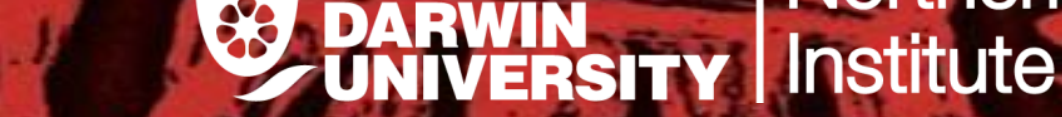

population-related aspirations articulated in the present day Developing Northern Australia agenda.

\section{Methods}

The analyses in this brief are based on 2006 and 2011 Census data as well as drawing on other Australian Bureau of Statistics (ABS) and Department of Immigration and Border Protection materials. Northern Australia is defined according to the geographical area referred to in the Green and White Papers and is the area to the north of the Tropic of Capricorn but also including the Alice Springs region of the Northern Territory in recognition of its importance for servicing surrounding communities and industry (Australian Government, 2014a).

The boundary of northern Australia extends across parts of the states of Queensland and Western Australia and encompasses the whole of the Northern Territory. Using this broad definition, a north-south split sees approximately 40.5 percent of the national land area and 5.2 percent of the total Australian population in the north. In this study we replicated the definition in the Green Paper and developed a custom geographic area based on Statistical Areas Level 2 (see Figure 1) to specify and extract customised Census tables from the ABS software Table Builder. Areas which were on the border of northern and southern Australia were allocated on the basis of the location of the majority of the population.

The Green Paper identifies the cities of Townsville, Cairns, Darwin, Mackay, Rockhampton, Gladstone and Karratha as the key urban areas (or 'zones' as they are labelled) in northern Australia. Interestingly, while the geographic scope of the policy includes Alice Springs which is larger than Karratha, this city is not mentioned in the context of growth in the urban zones of northern Australia. Our analysis of urban versus other populations and socio-economic change in northern Australia, incorporates those cities defined as 'Significant Urban Areas' by the Australian Bureau of Statistics in its publication Regional Population Growth (various editions). These are Townsville, Cairns, Darwin, Rockhampton, Mackay, Alice Springs, Mount Isa, Port Hedland, Yeppoon, Broome, Karratha and Emerald. 


\section{OHARIES Northern

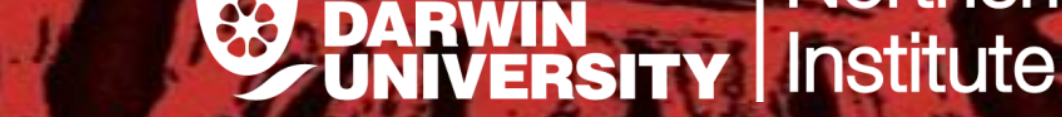

Figure I - Map of northern Australia as applied to the custom data in the analysis in this chapter.

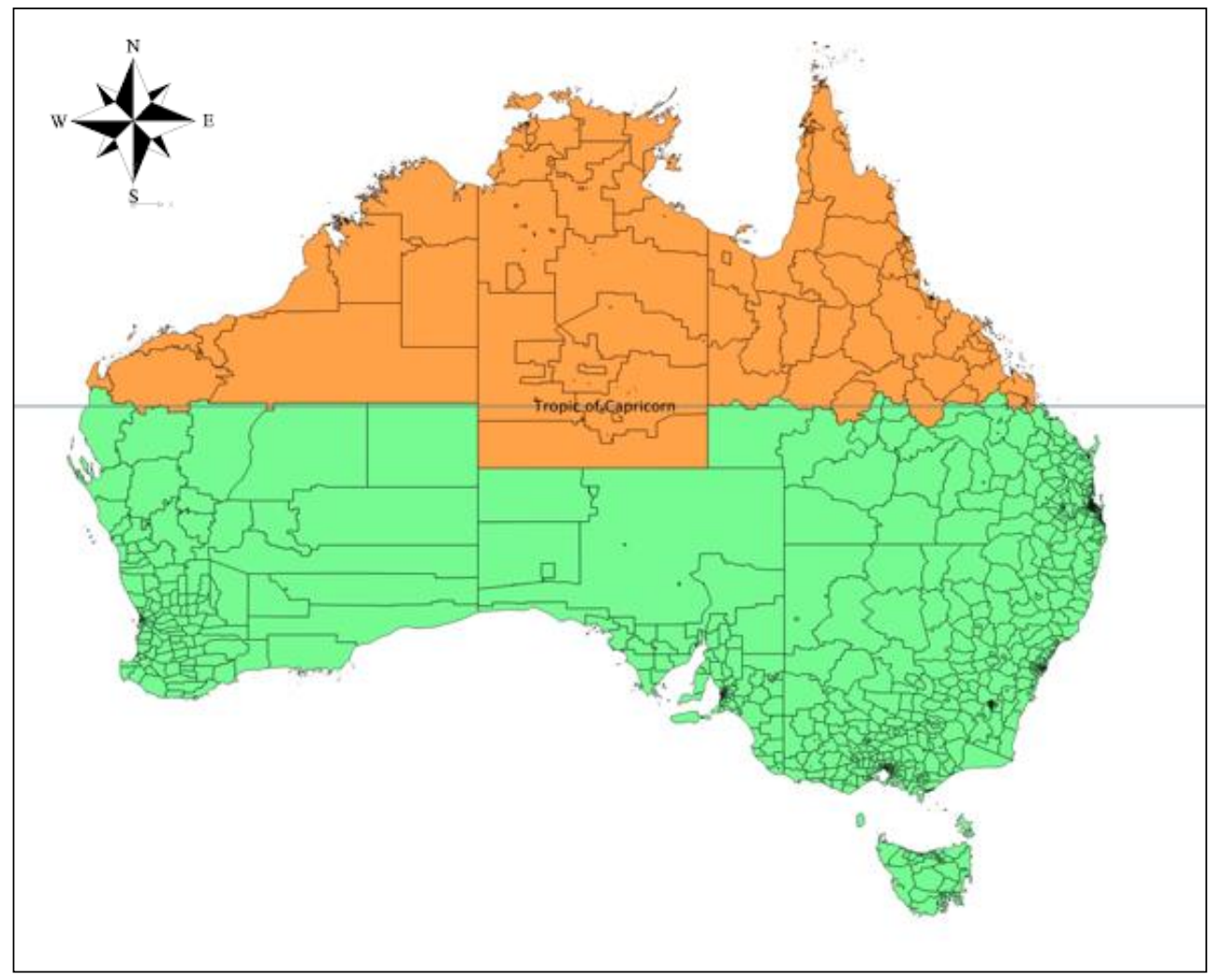

Source: Constructed by the authors using open source GIS software and ABS digital boundaries

\section{Results}

In the first part of the results section, we present fundamental demographic and socio-economic indicators for the region. We then analyse and comment on the population targets in the White Paper before presenting analysis which speaks to the three key population aspirations identified in the Green Paper (substantially increasing the population of urban zones in northern Australia, improving internal migration flows, and increasing international migration and the retention of international migrants). We then make overall comments and conclusions for the reader to digest the population related opportunities and challenges ahead as they relate to future northern economic development.

\section{I Fundamental demographic indicators for northern Australia}

Approximately five percent (just over 1.2 million) of Australian's resided in northern Australia in 2011, and this proportion was consistent with five years prior (Table 1). Applying linear growth rates would see the 2014 population estimated at just fewer than 1.3 million. Whilst the population grew by 12\% during 2006 to 2011 (compared to 8\% elsewhere), the overseas born population grew by $33 \%$, such that the overseas born representation in the population rose from $13 \%$ in 2006 to $16 \%$ by 2011 (compared to $27 \%$ in the rest of Australia by 2011). Meanwhile, the proportion of Australian Indigenous people living in the north fell by $2 \%$ and the ratio of men per 100 women (known as the sex ratio) increased from 105 to 107, but remained the same in southern Australia (at 97 men per 100 women). 


\section{$\because$ CHABLES Northern

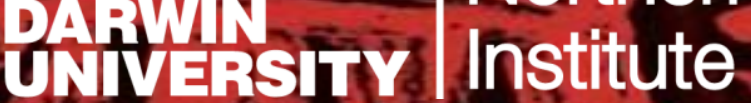

Table I - Key macro level demographic indicators for northern Australia

\begin{tabular}{|lrrr|}
\hline \multicolumn{1}{|c}{ Indicator } & 2006 & 2011 & Change \\
\hline Population of North Australia (NA) & $1,080,682$ & $1,206,090$ & $12 \%$ \\
\hline Population elsewhere & $19,965,922$ & $21,592,093$ & $8 \%$ \\
\hline Residents of NA born overseas (\%) & $13 \%$ & $16 \%$ & $33 \%$ growth \\
\hline Australian's living in North Australia & $5 \%$ & $5 \%$ & $0 \%$ \\
\hline Indigenous Australians living in NA & $30 \%$ & $28 \%$ & $-2 \%$ \\
\hline Sex ratio North Australia (v rest) & $105(97)$ & $107(97)$ & +2 men(no \\
& & & change) \\
\hline
\end{tabular}

Source: Author's calculations extrapolated from ABS Table Builder software

The resident population structure for northern Australia and the rest of the nation differ significantly with a much younger population evident in the north. In part this is due to the large and youthful Indigenous population who constituted 15\% of the population (around 140,000 residents) in 2011 (Figure 2). In northern Australia 22\% of the population were aged less than 15 years in 2011 compared to 19\% in the rest of Australia, while for the Indigenous population in northern Australia this was $35 \%$ compared to $20 \%$ for other residents. Conversely, seniors were under-represented in northern Australia where $9 \%$ of the population were aged 65 years and over compared to $14 \%$ in the rest of Australia. A 'bubble' in the age structure for northern Australia is evident at 25-29 years with a higher proportion evident in subsequent working ages up to 55 years.

Figure 2 - Age-sex structures for northern and the Rest of Australia (left chart), and northern Australian Indigenous and non-Indigenous residents (right), $201 \mathrm{I}$

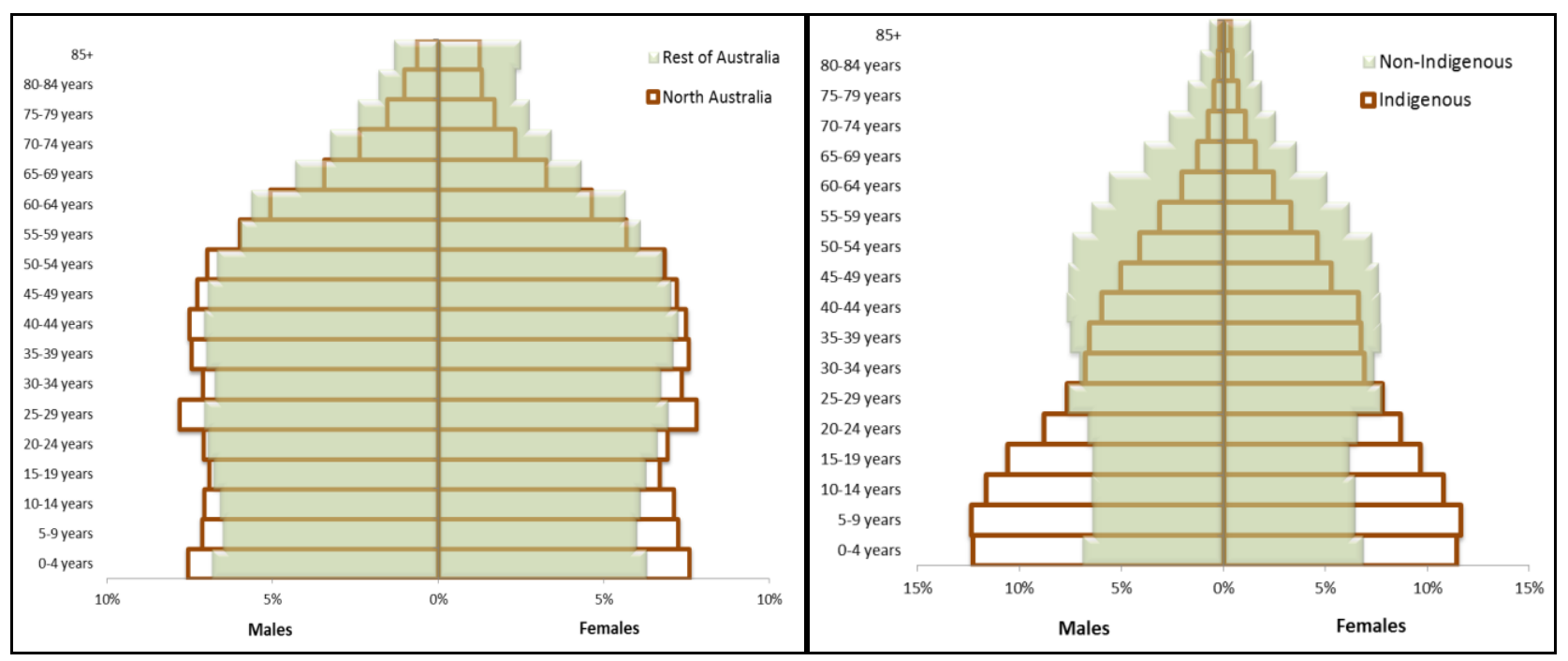

There was double the proportion of multiple-family households (6\%) in northern Australia in 2011, which may reflect the presence of a proportionally larger Indigenous population (although most 


\section{$\%$ CHARLES Northern

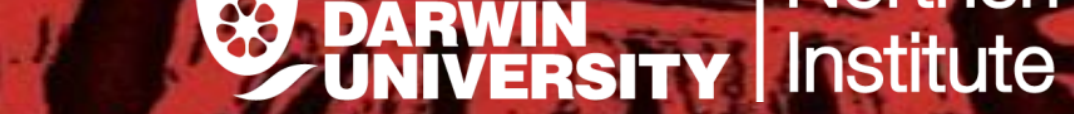

Indigenous people live in large cities in the south). Otherwise there were only relatively minor differences in the household compositions between the north and rest of Australia.

\subsection{Fundamental socio-economic indicators for northern Australia}

The top ten industries for employment in northern Australia are shown in Figure 3 (with all other industries combined into the category of 'Other'). These account for $79 \%$ of employment compared to $73 \%$ for the top ten industries in the rest of Australia (signifying a relatively higher reliance on few industries of employment). Mining, Public Administration and Safety (which includes the defence sector) and Accommodation and Food Services are proportionally more prominent employers in the north.

Figure 3 - Industry of employment, 20I I

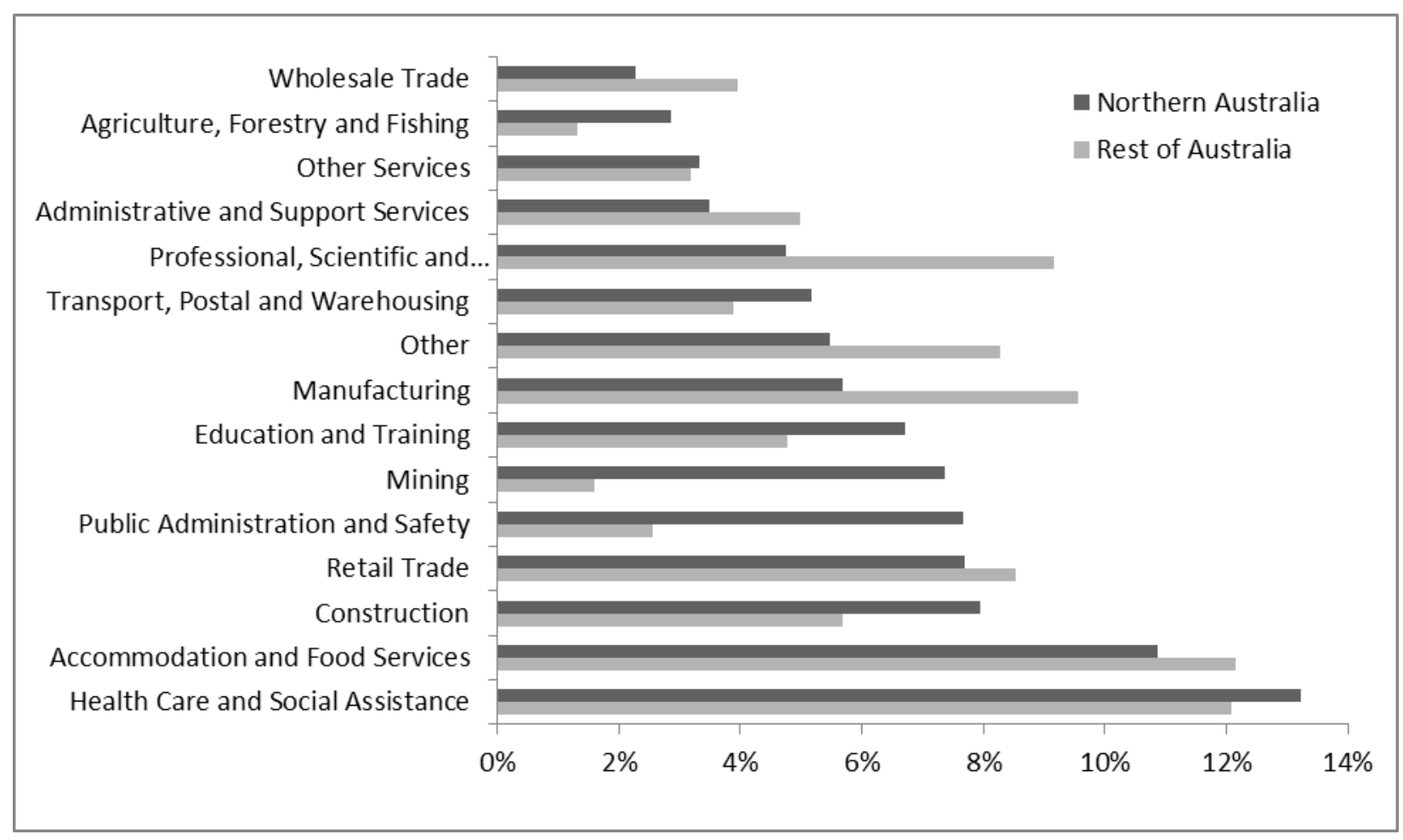

Source: Author's calculations extrapolated from ABS Table Builder software

Incomes in northern Australia were on average higher than elsewhere in 2011, with the exception of Indigenous residents. Despite their low incomes in comparison to others, a third of Indigenous residents in the north earned on average $\$ 1,000$ a week or more compared to $28 \%$ for the rest of Australia (Figure 4) and a lower proportion earned very low incomes of less than $\$ 200$ per week.

While mining is prominent in the north, it was only the fifth largest employer (of northern residents) in 2011. Substantial discussion and debate on the practice of fly-in-fly out (non-resident) workers across the north has transpired, and in particular for large resource based projects. Nevertheless, non-resident workers were prominent in other industries in the north in 2011 including in the Public Administration \& Safety, and Health Care \& Social Assistance industries. Numbers of non-resident workers in northern Australia grew by around 40\% during 2006 to 2011 


\section{$\therefore$ CHABLES $\quad$ Northern

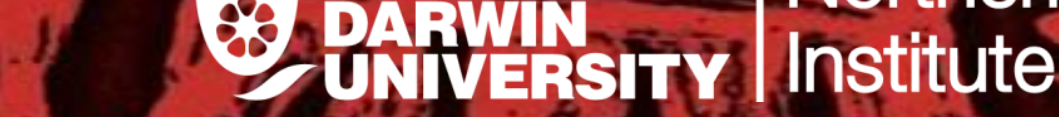

with $75 \%$ of these being males and with around double the proportion of averaging weekly earnings of more than $\$ 1,500$.

Figure 4 - Northern Australia income distributions, 20I I

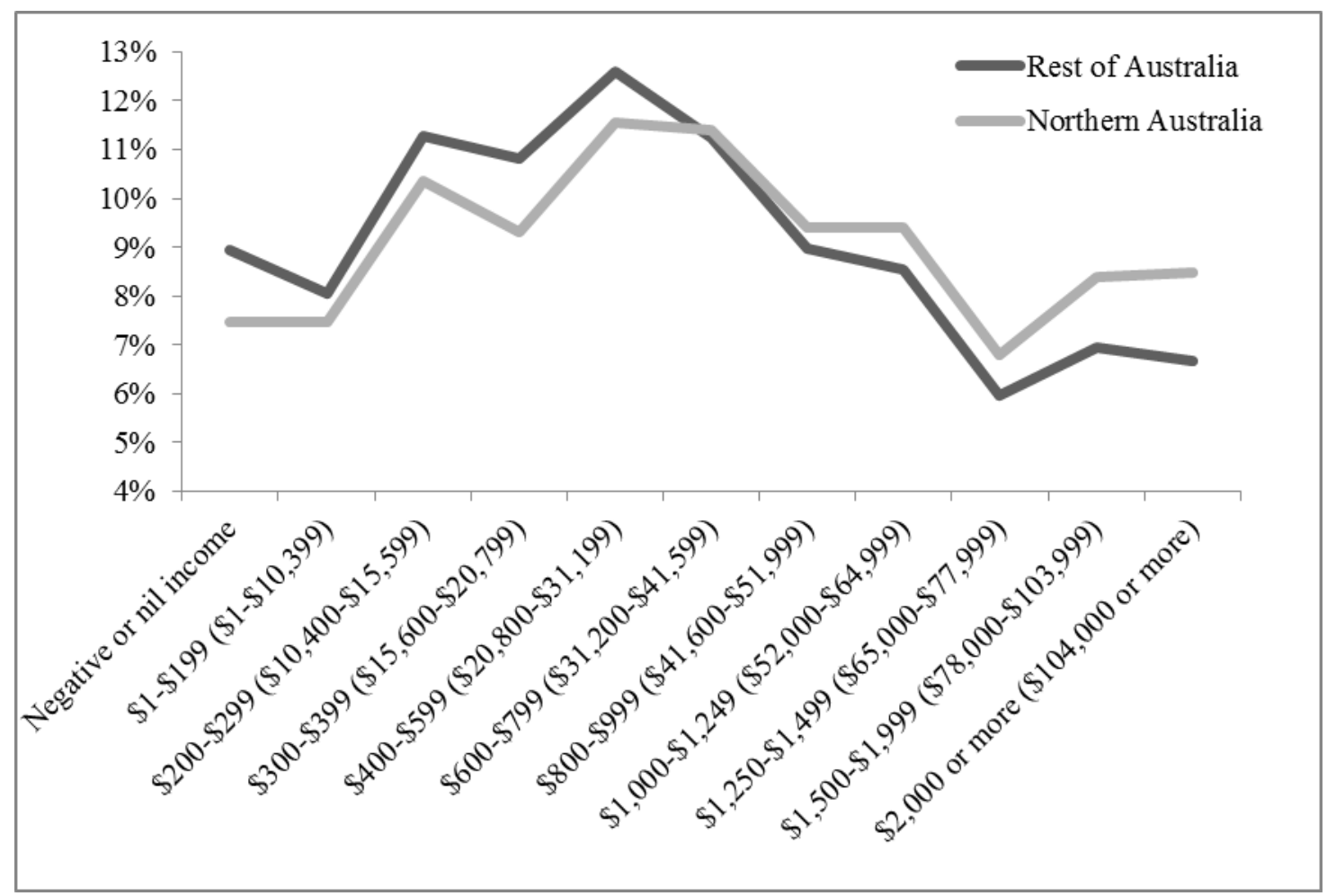

Source: Author's calculations extrapolated from ABS Table Builder software

A further noteworthy economic issue for the north is its low labour force participation rates for Indigenous residents. In 2011 the rate was 50\% in the north compared to $26 \%$ for non-Indigenous people (Table 2), and the Indigenous unemployment rate was three times higher than for nonIndigenous people at the same time.

Table 2 - Northern Australia and the Rest of Australia Labour force status, 201 I

\begin{tabular}{|l|c|c|c|c|}
\hline \multirow{2}{*}{} & \multicolumn{2}{|c|}{ Northern Australia } & \multicolumn{2}{c|}{ Rest of Australia } \\
\cline { 2 - 5 } & Indigenous & Non-Indigenous & Indigenous & Non-Indigenous \\
\hline Employed & $41 \%$ & $71 \%$ & $46 \%$ & $62 \%$ \\
\hline Unemployed & $9 \%$ & $3 \%$ & $9 \%$ & $4 \%$ \\
\hline $\begin{array}{l}\text { Not in the labour } \\
\text { force }\end{array}$ & $50 \%$ & $26 \%$ & $45 \%$ & $35 \%$ \\
\hline Total & $100 \%$ & $100 \%$ & $100 \%$ & $100 \%$ \\
\hline
\end{tabular}

Source: Author's calculations extrapolated from ABS Table Builder software

Attracting and retaining skilled workers is a point of discussion in the present day White and Green Papers. Educational data on individual's highest post-school level of qualifications are an indicator of the overall level of skills in the community. For those with a post-school qualification, a smaller proportion of non-Indigenous people held a Bachelors level or above qualification (19\% compared 


\section{OCHARLES $\quad$ Northern

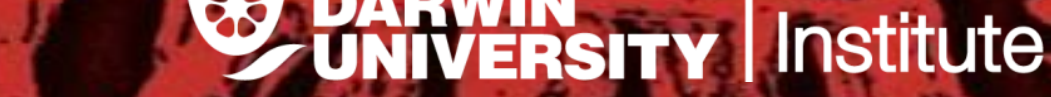

to $31 \%$ ) in 2011. However, for Indigenous people the proportion with a Bachelor level or above qualification is higher in northern Australia (Figure 5). A far higher proportion of Indigenous people in northern and southern Australia hold Certificate level qualifications.

Figure 5 - Highest level of post-school qualifications by Indigenous status, 201 I

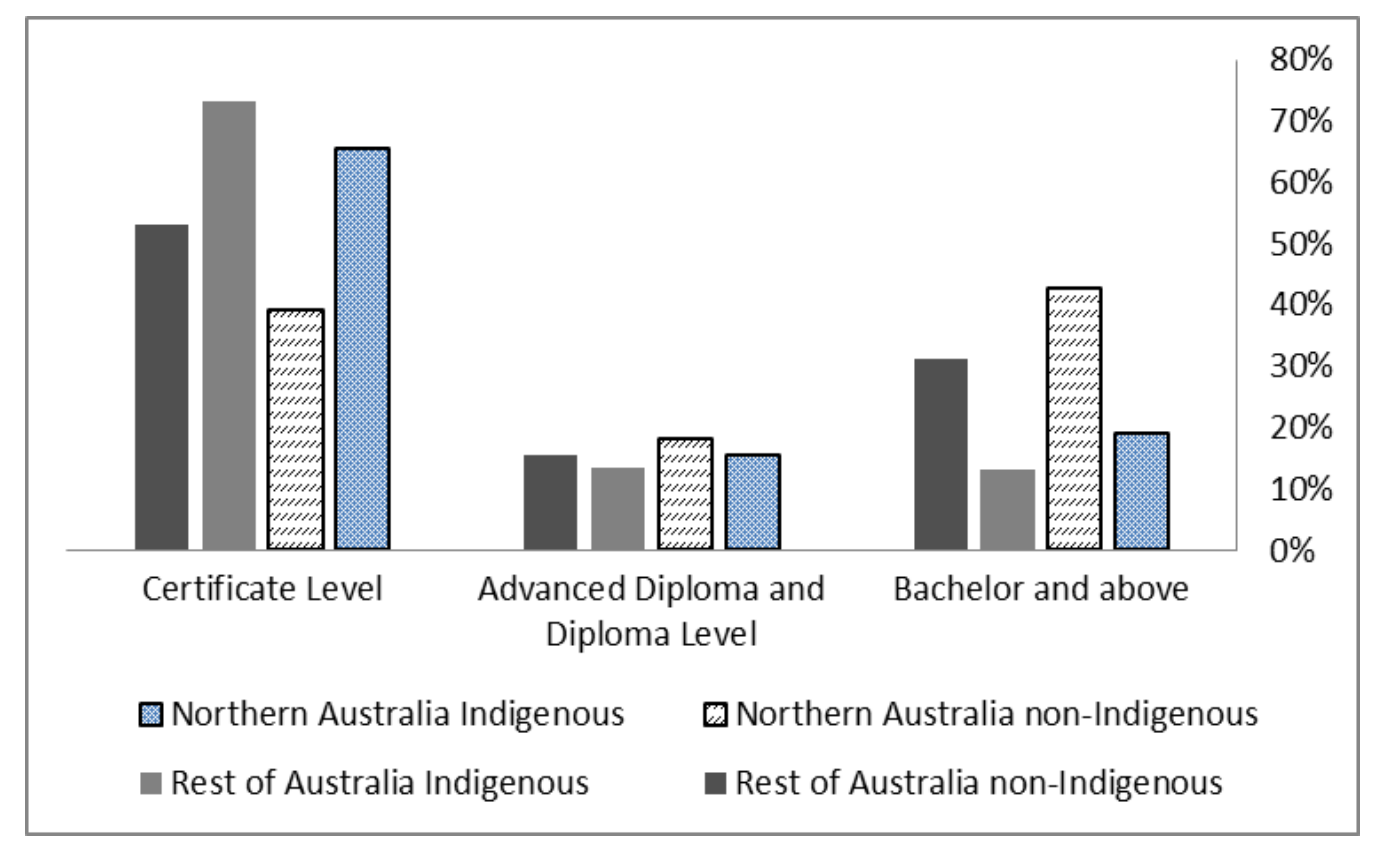

Source: Author's calculations extrapolated from ABS Table Builder software

As a measure of the capacity for northern Australia to develop the industrial and services sectors, improving Internet rates can be considered as an important pre-cursor and, indeed, a number of Green Paper submissions identified a lack of information communications technology infrastructure. In 2011, 21\% of households in northern Australia did not have any form of Internet connection, compared to $14 \%$ in the rest of Australia (Figure 6). Of those households in the north who had a connection in 2011, less had broadband connections compared to the rest of Australia (71\% compared to $80 \%)$. 


\section{OCHARIES Northern

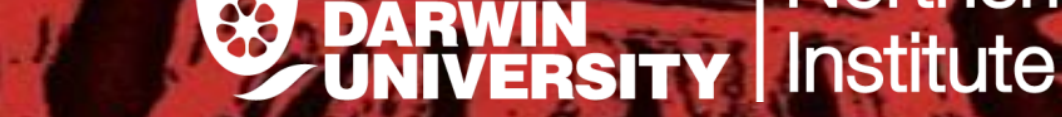

Figure 6 - Type of Internet connection for households, 20II

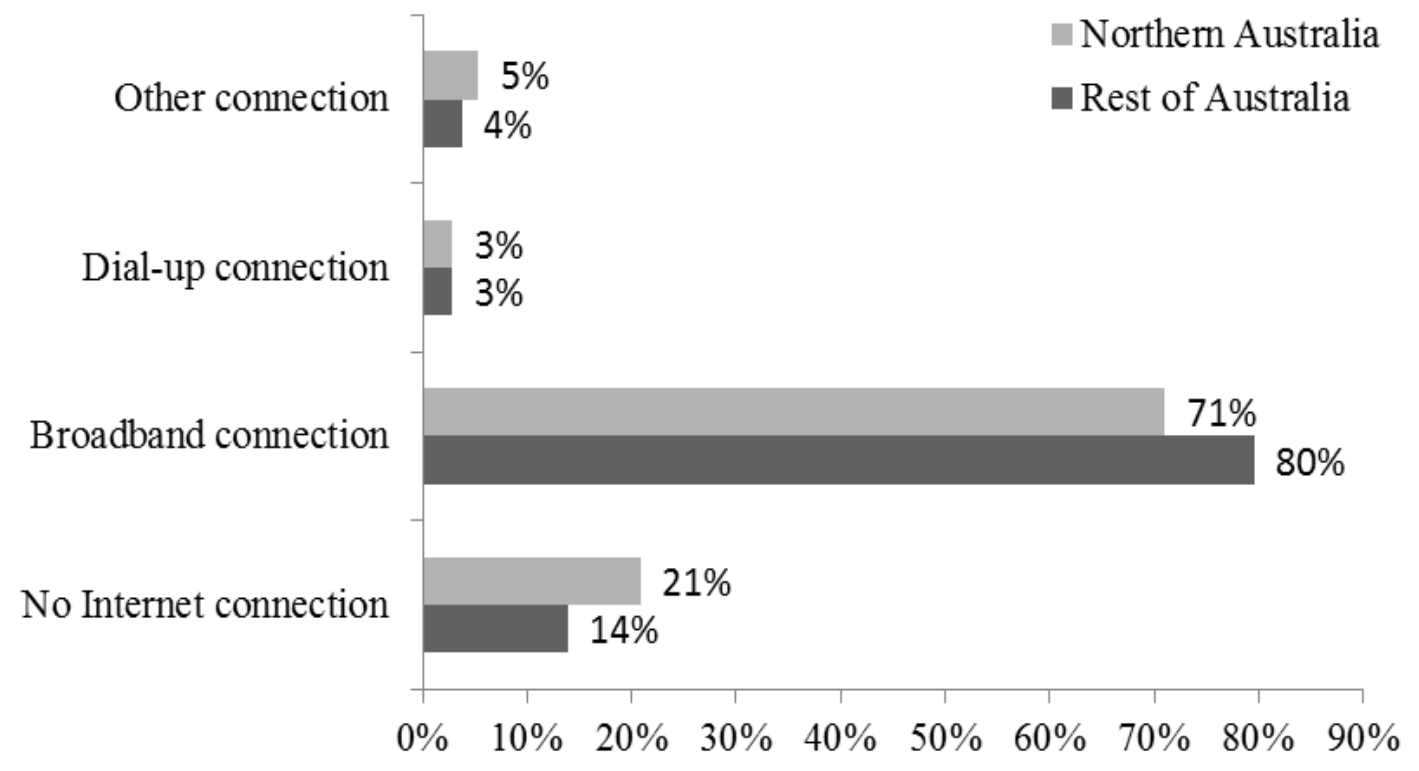

Source: Author's calculations extrapolated from ABS Table Builder software

\subsection{The White Paper population targets}

The White Paper outlines the intention for population growth to achieve cities of more than a million residents and for the region to grow to between four and five million residents by the year 2060. Table 3 shows the estimated 2014 population for the larger cities and towns in northern Australia with the final column demonstrating the additional per annum growth required between 2015 and 2060 for each to reach a population of one million. While the White Paper did not set a year for reaching the cities targets, for demonstration purposes we have applied the same year (2060) as for the target expressed for the region as a whole to reach a population of 4.5 million (the final row in the table).

Table 3 demonstrates that, although the additional per annum growth rates for some cities to reach one million residents by 2060 (notably Cairns, Townsville and Greater Darwin) may appear to be low and achievable, in reality achieving these year on year is highly unlikely. This is because the average annual growth rates for most during the decade leading up to 2014 were well above long-term averages, such that rates of all of these cities can be expected to be below the ten year average for most of the period in question. For example, the ten year average growth rate for Greater Darwin (during 2004 to 2014) was 2.8\%, slightly above the average from 1991 to 2014 (2.7\%). To achieve 1 million residents by 2060 the city would need to grow by $4.5 \%$, well above the recent relatively high rates it has experienced. The second factor to consider in assessing the likelihood of achieving the targets is that just one year of below target growth will require growth rates in subsequent years to be higher still to effect a 'catch up'.

For the region as a whole to reach 4.5 million residents (half way between the targets outlined in the White Paper) additional growth of $0.5 \%$ per annum is required. While this additional growth rate may not on the surface appear to be particularly high, achieving this would require a large 
transformation in the growth dynamics of the region. Not least, almost all of the growth in the region is in the major urban centres with the rest in stagnation or decline. Consequently, cities would require growth over and above that shown in Table 3 to compensate for low growth elsewhere. In the following sections we discuss some of the reasons for these statements by way of presenting of analysis of the past and existing population of northern Australia and relating these to population aspirations documented in the Green Paper.

Table 3 - Population estimates and required growth rates to reach White Paper population targets

\begin{tabular}{|l|l|l|l|l|l|c|}
\hline & & & & Av. Growth \\
& $\begin{array}{l}2014 \\
\text { Population } \\
\text { Estimate }\end{array}$ & $\begin{array}{l}\text { Target } \\
\text { population }\end{array}$ & Difference & $\begin{array}{l}\text { Av. } \\
\text { Annual } \\
\text { to reach } \\
\text { growth } \\
\text { (2004 to } \\
\text { 2014) }\end{array}$ & $\begin{array}{l}\text { Additional } \\
\text { growth p.a. } \\
\text { needed 2015- } \\
60\end{array}$ \\
\hline Alice Springs & 28,667 & $1,000,000$ & 971,333 & $8.2 \%$ & $0.8 \%$ & $7.4 \%$ \\
\hline Broome & 17,311 & $1,000,000$ & 982,689 & $9.4 \%$ & $2.3 \%$ & $7.1 \%$ \\
\hline Cairns & 158,985 & $1,000,000$ & 841,015 & $4.2 \%$ & $2.9 \%$ & $1.3 \%$ \\
\hline Darwin & 139,617 & $1,000,000$ & 860,383 & $4.5 \%$ & $2.8 \%$ & $1.7 \%$ \\
\hline Karratha & 26,649 & $1,000,000$ & 973,351 & $8.4 \%$ & $4.9 \%$ & $3.5 \%$ \\
\hline Mackay & 123,383 & $1,000,000$ & 876,617 & $4.8 \%$ & $2.8 \%$ & $1.9 \%$ \\
\hline Port Hedland & 16,810 & $1,000,000$ & 983,190 & $9.5 \%$ & $2.3 \%$ & $7.2 \%$ \\
\hline Rockhampton & 83,439 & $1,000,000$ & 916,561 & $5.7 \%$ & $1.5 \%$ & $4.2 \%$ \\
\hline Townsville & 192,038 & $1,000,000$ & 807,962 & $3.7 \%$ & $2.7 \%$ & $1.0 \%$ \\
\hline Northern Australia & $\mathbf{1 , 2 9 0 , 0 6 7}$ & $\mathbf{4 , 5 0 0 , 0 0 0}$ & $\mathbf{3 , 2 0 9 , 9 3 3}$ & $\mathbf{2 . 8 \%}$ & $\mathbf{2 . 3 \%}$ & $\mathbf{0 . 5 \%}$ \\
\hline
\end{tabular}

Note: The sum of towns and cities is not intended to equal the population of northern Australia

\subsection{Results for Green Paper population related ambitions}

In this section we analyse demographic and socio-economic characteristics of northern Australia which are pertinent to assessing the challenges and opportunities associated with populationrelated ambitions that have been outlined in the Green Paper for Developing Northern Australia.

\subsection{Significantly growing northern Australia's urban zones}

In 2011, the urban zones of northern Australia (defined in the Methods section above) accounted for $69 \%$ of the population and had grown by $18 \%$ from 2006 , compared to just $3 \%$ for the remainder of the region. Indigenous residents too increasingly gravitated towards the urban zones with their share of the region's Indigenous population growing from $32 \%$ to $41 \%$ and the Indigenous population in urban zones growing by $21 \%$ over the five-year period (Table 4). However, the proportion of population in urban zones who were Indigenous in 2011 fell, while rising in the remainder of the region, indicating relatively large growth in the non-Indigenous population in urban areas since 2006. The population of urban zones grew by $18.4 \%$ from 2006 to 2011 in comparison to just $2.6 \%$ for the remainder of northern Australia. 
There were 104 men for every 100 women in northern urban zones in 2011 compared to 113 per 100 in the remainder of the region. This male bias in the population had increased for both areas during 2006 to 2011, especially outside of the urban zones. Meanwhile, urban zones featured a larger and increasing share of overseas born migrants in the population at $18 \%$ in 2011 compared to $11 \%$ elsewhere in the north. The proportion of the population under 15 years of age was around 22\% across the north and remained consistent during 2006 to 2011. However, the proportion aged 65 years and over grew in both the urban zones and remainder of northern Australia from 2006 to 2011, and can be anticipated to grow more substantially into the future (see research brief Now You See Us! A Report on the Policy and Economic Impacts from Rapid Growth in the Number of Senior Territorians).

Table 4 - Key demographic indicators for northern Australian urban zones, 2006 and 20 I I

\begin{tabular}{|l|c|c|c|c|}
\hline \multirow{2}{*}{ Demographic indicators } & \multicolumn{2}{|c|}{2006} & \multicolumn{2}{c|}{2011} \\
\cline { 2 - 5 } & Urban zones & Remainder & Urban zones & Remainder \\
\hline Population share of the region & $57.1 \%$ & $42.9 \%$ & $60.6 \%$ & $39.4 \%$ \\
\hline Indigenous share of the region & $34.6 \%$ & $65.4 \%$ & $37.5 \%$ & $62.5 \%$ \\
\hline Indigenous proportion in population & $9.1 \%$ & $22.7 \%$ & $9.3 \%$ & $23.8 \%$ \\
\hline Proportion born overseas & $15.2 \%$ & $10.3 \%$ & $17.7 \%$ & $12.2 \%$ \\
\hline Men per 100 women & 102.6 & 107.5 & 102.5 & 113.6 \\
\hline Proportion under 15 years & $22.1 \%$ & $24.2 \%$ & $21.5 \%$ & $22.3 \%$ \\
\hline Proportion over 65 years & $8.7 \%$ & $9.2 \%$ & $9.2 \%$ & $9.8 \%$ \\
\hline Dependency ratio & $30.8 \%$ & $32.2 \%$ & $30.7 \%$ & $32.1 \%$ \\
\hline
\end{tabular}

Source: Authors calculations extrapolated from ABS Table Builder software

\subsubsection{Improve net internal migration flows between the north and the rest of Australia}

In parts of northern Australia, net interstate migration flows are most often negative, with more residents leaving than arriving. This has certainly been the case for the Northern Territory which recently experienced record net interstate migration losses and has seen 20 successive quarters of negative net interstate migration, totalling a net loss of just under 10,000 residents and with a gross loss of around 26,000 in the eighteen months to December 2014 (ABS, 2015). Nevertheless, parts of the north have experienced relatively large rates of population growth in recent years including Townsville, Cairns and in the Pilbara region. Overall, net interstate migration to northern Australia during 2006 to 2011 was 16,500 , with $75 \%$ of this attributable to the non-urban areas of the north. Growth in urban areas meanwhile has been driven by international migration, natural increase and internal migration within the region (from remote areas to urban zones). Critical to improving net interstate flows for northern Australia are an understanding of who comes and who goes. Figure 7 demonstrates the concentration of interstate migration, in both directions, of 


\section{OHABLES Northern

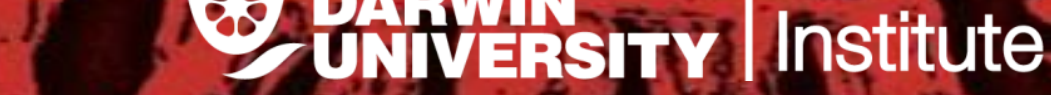

persons aged in their 20s and 30s, especially for migration into northern Australia from outside the region. The broad shapes of the in and out migration profiles are similar for men and women.

Figure 7 - Northern Australia migration age profiles, 2006 to 2011

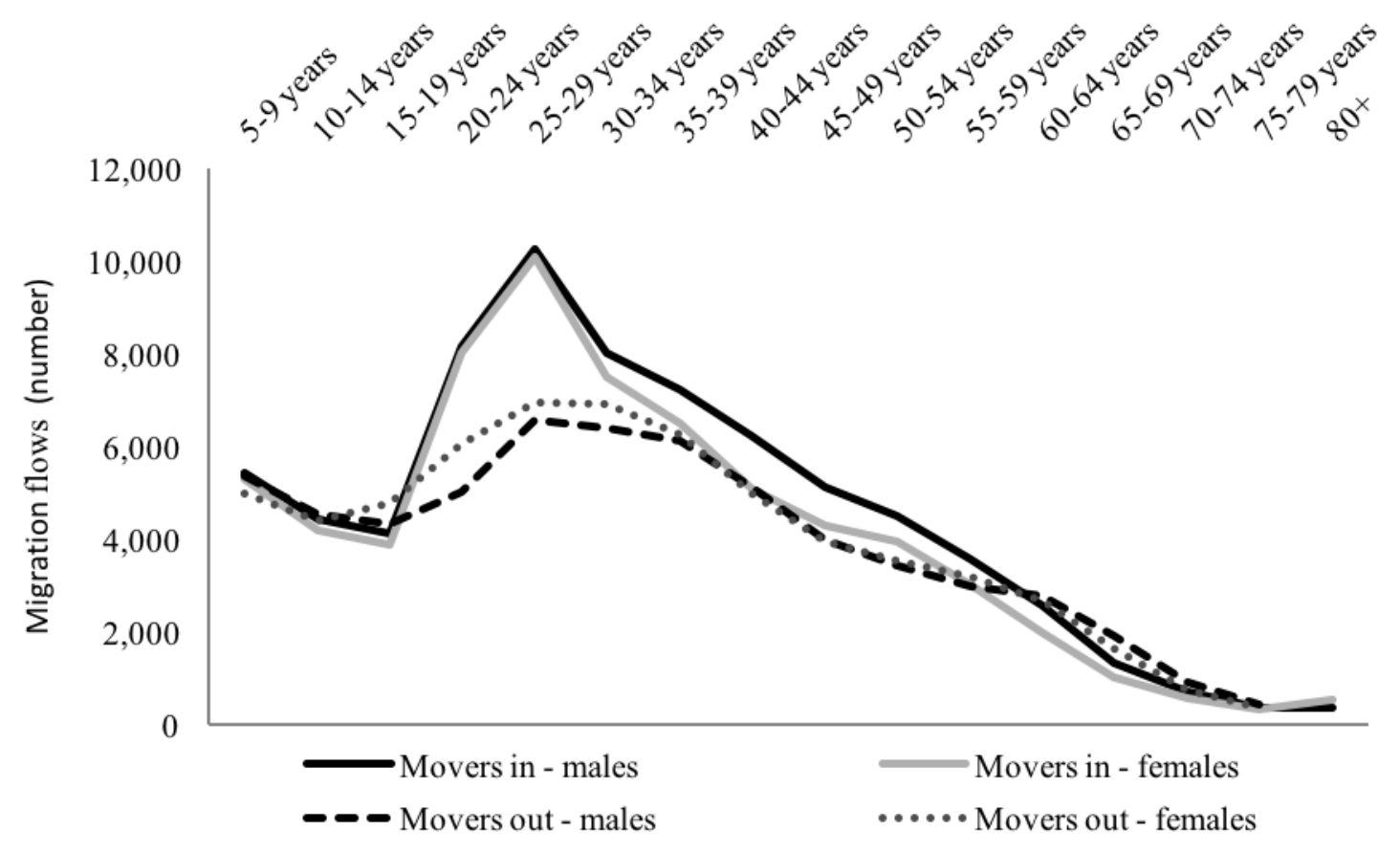

Source: Authors calculations extrapolated from ABS Table Builder software

Data also show a net positive contribution to population growth from interstate migration across all ages, except those 55 years and older and those aged 10-19 years (Figure 8). The former highlights the loss of seniors while the latter suggests is a significant 'brain drain' to southern areas, particularly for females, for further education. The gender differences in net interstate migration also demonstrate the progression of the region towards a greater male bias with 10 extra men per 100 women moving into the region but 3 fewer men per 100 women moving out. 


\section{OCHABIES Northern

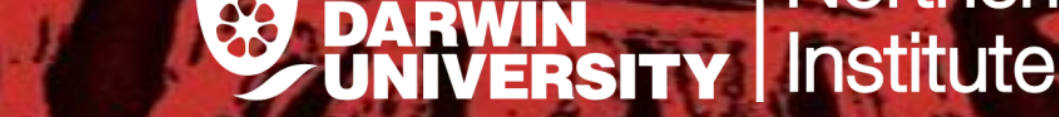

Figure 8 - Net interstate migration by age, northern Australia, 20I I

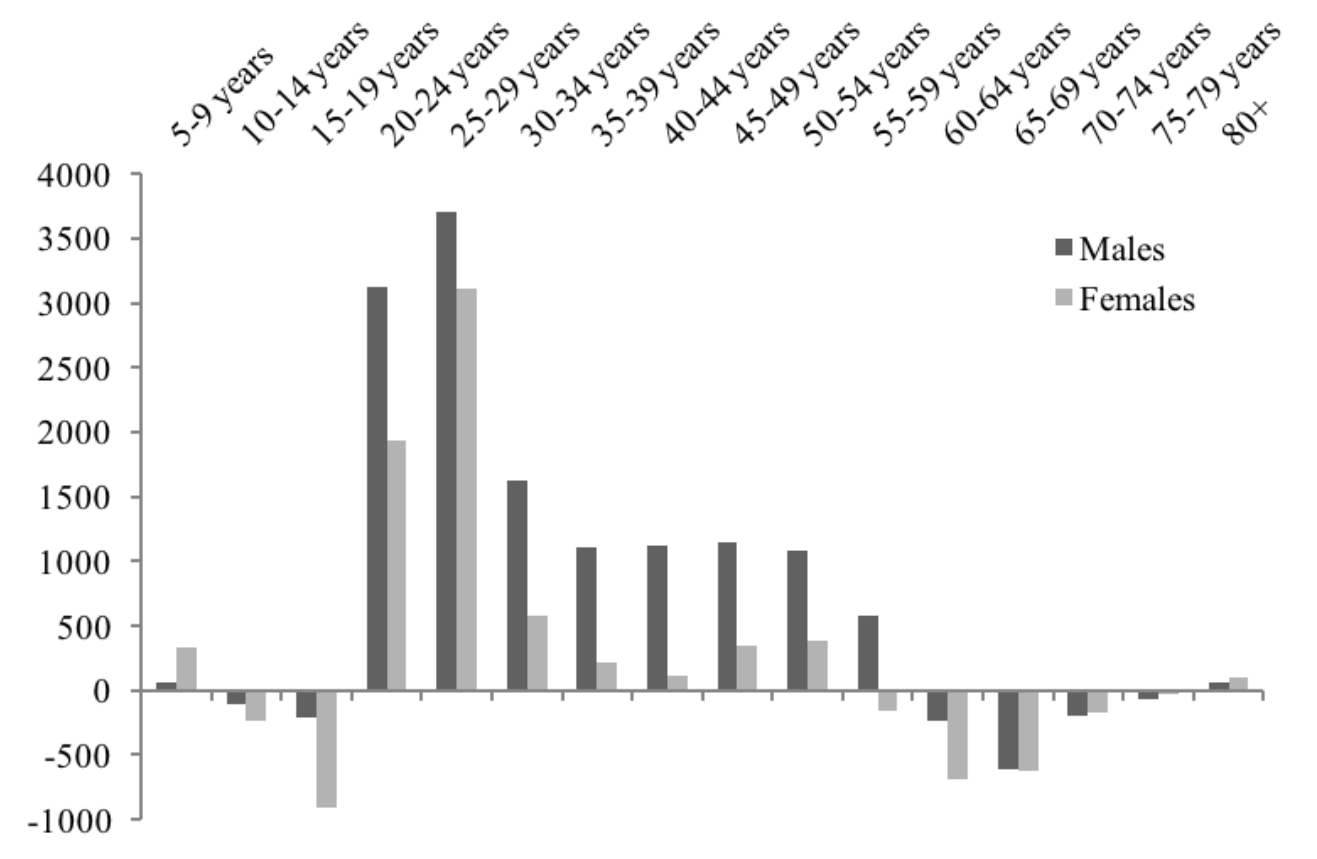

Source: Authors calculations extrapolated from ABS Table Builder software

Turning to specifically those who have moved out of the region, Census data provide some indications on the associated factors. Those employed in the Public Administration and Safety and Education and Training sectors, for example, were more likely to have left the region, as were those who were unemployed. Those not participating in the labour force were more likely to have stayed.

Although no region-wide research on motivations and triggers for leaving northern Australia for interstate are available, research specifically for the Northern Territory provides some clues (Cunningham and Beneforti, 2008). A survey of people who had left the NT in 2006 identified women, on average, left at an earlier age than men. Leavers who did not know if they might return to the NT cited financial incentives, improvements to health services, career opportunities and housing subsidies as the main incentives that might attract them back as residents. Likewise, a large survey of NT seniors' has reported that those considering leaving the NT within five years have identified the cost of living (and particularly for housing), as a major motivator for leaving; as well as the desire to be closer to family (Zeng et al., 2015).

None of these data, however, incorporate full accounts of movements into and out of the region as they preclude temporary visitors (tourists) and non-residents (defined as people who are or intend to be present for less than six months). This group has grown markedly (by $35 \%$ in the NT, during 2006 to 2011, for example) and, paradoxically, given the consistent message about cost of living issues in the north, exhibit significantly higher incomes than the average northern Australian resident (Carson and Taylor, 2012). 


\section{CHABLES Northern

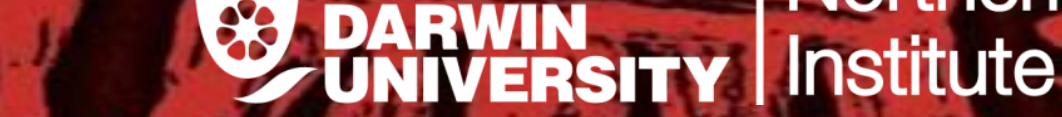

\subsubsection{Increase international migrant numbers in the north}

There are significant structural and compositional differences between northern migrants and the rest of Australia, as well as between new arrivers and long-term overseas born residents of the north. Not least, proportions of overseas born in the population (16\%) are significantly below the rest of Australia (27\%), suggesting there is potential to increase numbers in the north.

However, realising increased shares of international migrants to the north will depend on policies that are targeted towards a complex range of issues, aside from those associated with discussions on visas and the use of skilled workers from overseas. These include redressing existing internal distributions of international migrants within Australia, which have long been heavily skewed towards the capital cities and their surrounding urban areas. In Queensland, for example, around $70 \%$ of recent arrivers settled in Brisbane or on the Gold Coast; in Western Australia around 90\% of all new migrants settle in Perth, while in the Northern Territory $75 \%$ of recent migrants settled in Darwin or Palmerston. Northern jurisdictions have attracted zero to four percent of recent migrants to the individual States or Territory (Figure 9).

Figure 9 - Recent international migrant distributions within northern jurisdictions

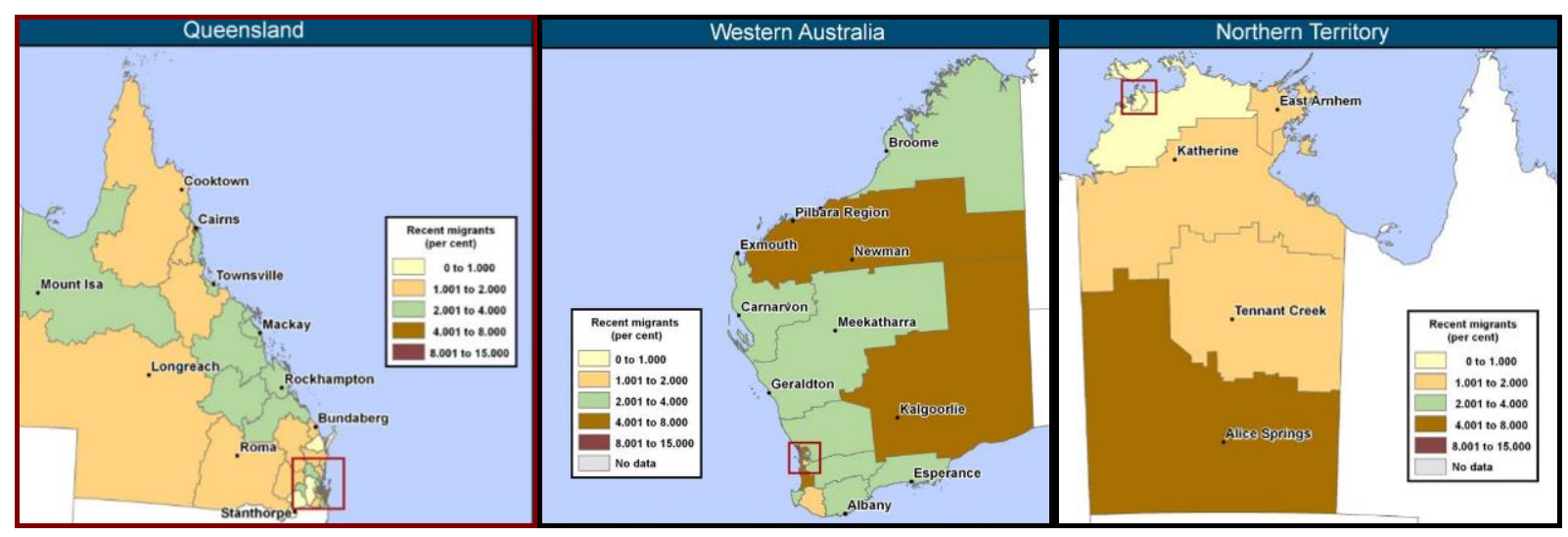

Source: Department of Immigration and Border Protection (2014)

These figures highlight there are challenges inherent in encouraging new overseas migrants to settle in sparsely populated northern regions. While State and Territory specific migration programs for encouraging northern and regional settlement by international migrants (for example the Regional Skilled Migration Program) are in place, only a small portion choose to do so.

A further and major barrier to more substantial international (and indeed interstate) migration flows to northern districts is the inability to attract and retain women. This is indicated in the ratio of men to women for overseas born in the north, at 119 men per 100 women (much higher than for others at 107 per 100), and net migration flows to and from the region, which show males contributing at three times the rate on a net basis. The magnitude of the female deficit in the north is revealed in Figure 10, which shows the 'missing' females in the north in comparison to the rest of Australia and broken down by overseas born females and others. There are large deficits of overseas born females aged $0-4$ and in their late teens to early 20 s, as well as from 60 years 


\section{OCHABLES Northern

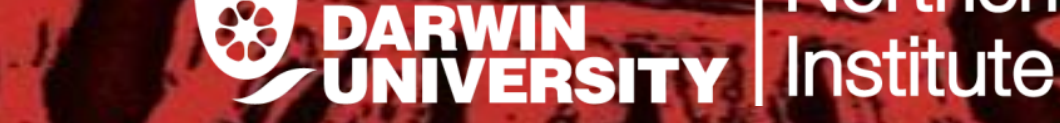

onwards. For non-migrants, deficits are relatively large at all ages from 30 years onwards, peaking for ages 55 years and above.

Figure 10 - The 'missing' women of northern Australia, 20I I

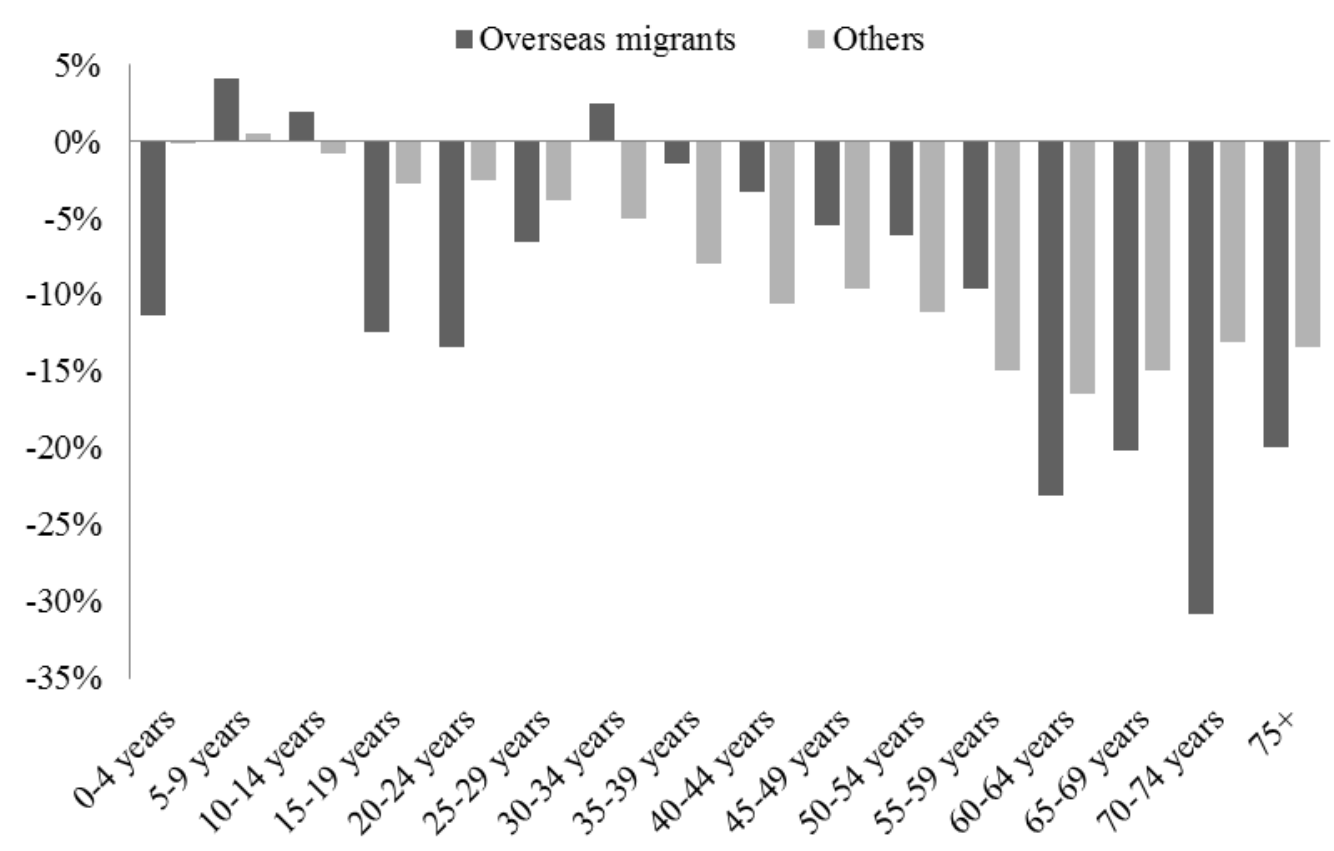

Source: Authors calculations extrapolated from ABS Table Builder software

Note: These calculations show the percentage difference in the number of women per 100 men between northern Australia and the rest of Australia.

A male biased population signifies demographic and social imbalance in communities and is a feature of most of the northern areas in developed nations (Taylor and Carson 2014). The predominance of male overseas born migrants settling in northern Australia is likely in part to be a function of noteworthy growth in the skilled stream migration classes. Skilled jobs are heavily male biased and this may explain a continuing male bias in the overall population. Nevertheless, peak ages for missing females suggest a large deficit of females aged above 55 years as well.

\section{Discussion and Conclusions}

Much of the analysis presented in this brief involves comparisons and contrasts at a range of geographic and demographic scales: northern Australia compared to the rest of Australia; urban areas in the north compared to others; overseas born compared to others; and so on. These are just some of the levels at which the significant differences in the demographic and economic makeup across the region and between the region and elsewhere can be observed. There are also, of course, substantive intra-regional and cross-border differences warranting further research. For example, some areas like the Pilbara, are in the midst of a significant downturn as the price of Iron Ore has plummeted, while the economy of the Northern Territory is purportedly booming from large resource projects but at the same time has lost record numbers of residents through net negative interstate migration during 2013-2014 (Payer and Taylor, 2015). 
These sorts of intra-regional differences in population systems and in the interrelationships between population and economy are acknowledged to some extent in the White and Green papers, but the apparent disparate and segregated natures of these are understated. Population systems are relatively discrete, having been built and maintained around specific economic functions, which may well be temporary and certainly re-enforce the sorts of population imbalances common across northern jurisdictions. Discrete areas of economic activity and population settlements themselves are largely poorly integrated when it comes to transport and the flows of labour and capital.

What is common across the region is an increasing dependence on externally sourced capital and labour. Such conditions make the challenge of 'developing from within' increasingly difficult and engender circumstances under which divergences in population and socio-economic conditions between sub-groups, for example between urban and non-urban residents or Indigenous and nonIndigenous residents, can be expected to maintain and grow (Taylor, et al., 2011). These sorts of challenges are long standing for northern peripheral areas:

"Taking the structure and functioning of the Arctic regional economies and the degree of economic dependence as a point of departure... The fundamental problem is still the dependency Arctic regions have on their mother economies in the south".

(Winther, 2010, p. 1)

The loss of university entrants to southern regions also emphasises the 'brain drain' and loss of future innovation capacity associated with long-term migration patterns.

Several indications are evident in this chapter of a growing divide in the north between employed, educated and affluent residents (and non-residents), who's migratory patterns align with continuing such lifestyles, and a relatively non-migratory, under-educated and low-income cohort. The latter includes, but certainly is not limited to, many Indigenous residents in the north. Current approaches and articulations for northern development may identify these issues, but they provide very little in the way of direct suggestions on avoiding or rectifying the potential for a 'stuck underclass' to continue to emerge and grow. Conversely, population aspirations articulated in the Green Paper may actually enhance the worrying trend towards a further male bias, a highly mobile high income class and discrete geographical areas where 'boom and bust' cycles attract and then repel increasing numbers of affluent men. The Pilbara in Western Australia and Nhulunbuy in the Northern Territory (both areas suffered significant out-migration when the mining operations ceased) are prime examples where the critical question is 'who is left' after those who have the means to leave have done so? In such settlements there is also collateral damage to investors in property and establishing businesses to consider.

Collateral 'demographic damage' also occurs from the downstream social and financial consequences of 'discrete booming and busting'. Socially, women are less likely to tolerate the sorts of effects from a strong male bias in populations noted in much of the research on 'boomtowns' (Taylor and Carson, 2014), including increasing crime, anti-social behaviour and health issues from risk taking. Financially, boom times increase the cost of living in discrete areas; particularly housing costs, a primary factor in motivating people of all ages to leave the region. The 
focus on urban growth, interstate migration and growing overseas migrant numbers says little about growing from within. Urban zones are already far outstripping 'the rest' in growth, international migrants are growing significantly (especially the skilled intake), and interstate migration flows are supporting the types of economic activities which might lead to further growth. This leaves the impression of both unrealistic targets in the White Paper (as our short section of analysis on the likelihood of reaching these shows) and an extemporaneous incorporation of the population ambitions embedded in the Green Paper. While the latter certainly incorporates some relatively sophisticated thinking on the issues of population change and growth, the approach is timid in terms of broaching the difficulties of encouraging 'growth from within'. The current iteration of developing the north, therefore, continues the focus on securing growth from externally sourced labour and capital and on sending goods and services overseas; notably to Chinese markets which are portrayed in both documents as ready and waiting to consume our goods and services in large volumes.

A solution to the issue of generating long term growth from within is both readily apparent from the analysis in this brief, but also exceedingly difficult: to attract and retain more women. The difficulties in achieving this have been laconically laid out by Carson and Schmallegger in their 2009 article titled 'Why don't women like Darwin?' (Carson and Schmallegger, 2009). In summary, northern peripheries are subject to demographic lock-in as a result of legacy industries being highly male preferenced (fishing, agriculture and mining, for example). Such industries 'trap' men into patterns of employment which, although changing in line with companies engaging more labour efficient processes, contribute to social amenity which women do not like or want. Conversely, large cities 'down south' offer better education and career prospects, a chance for more favourable community amenity and likely are closer and better connected to locations of family members for support with children and finance. There are firm indications of these issues in the analysis in this chapter which contrasts the sex ratios between urban areas in the north and the remainder, as well as between the north and rest of Australia; as well as in the gender and age profiles of migration in to and out of the region.

These issues might also lead us to question whether, and why, a bigger population is seen to be inherently desirable at the expense of a more appropriate population composition (which would include an economy which sources more labour from its residents). Throughout the history of inquiries and reports on the potential of the region, readers are left in no doubt that not only is bigger best, but that (somehow) a complex population system featuring a great diversity of settlement types, settlement sizes, growth rates, migration rates, mortality rates and ethnic compositions (to name a few population characteristics) will 'deliver' the required demographic outcomes (age and gender balance, skills set and so on) for up-scaled development. Ironically, it is extreme population growth rates in Asia (to the north of 'our north') that have long been cited as the impetus for the underlying assumption that northern Australia must grow.

Aside from the issue of environmental sustainability, growth in the north might also be examined in light of two other major and long-term demographic trends affecting the region and its ability to cater to its population's service and infrastructure needs. First, like the rest of the world, northern Australia is ageing. But the onset, scale and timing of impacts are varied geographically because of 


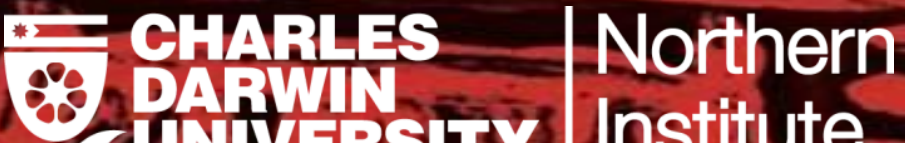

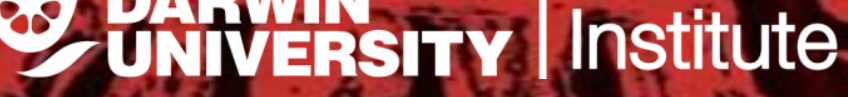

the great diversity in population attributes across space (Zeng, et al., 2015). Not least, population ageing as a process in the north will be firmly influenced by ageing in the Indigenous population. In the Northern Territory, for example, above 5\% growth per annum (although from a small base) is anticipated in Indigenous residents who are aged 65 years or more up to the year 2041. The dispersed residency of these will create specific challenges for servicing health and other needs.

Secondly, the spatial distribution of Aboriginal and Torres Strait Islander people in Australia has undergone accelerated and dramatic change in recent decades, featuring increasing proportions living in southern capital cities and their hinterlands, and a reducing proportion in the north of the nation. Since WWII, for example, the Indigenous share in States and Territories located wholly outside of northern Australia (i.e. NSW, VIC, SA, TAS, and ACT) more than doubled from $21 \%$ to $48 \%$ (ABS, 2014). More recently, the Indigenous share in northern Australia declined from $30 \%$ to 28\% (2006 to 2011) while increasing proportions are residing in large cities (Taylor and Bell, 2013). The impetus for this big shift is 30 years of differential Indigenous population growth between major cities and northern Australia, with large measured increases in metropolitan areas evident. Despite absolute growth, the share living in the north has declined. During 1981 to 2006, for example, the Indigenous population of the NT grew by $85 \%$, but its share of the national Indigenous population (which grew by $185 \%$ ) fell from $18 \%$ to $12 \%$, then to $10 \%$ in 2011 (Taylor \& Bell, 2013).

Four main factors are at play including 'new Indigenous identifications' in the south of Australia, the migration of Indigenous residents from north to south, a growth in mixed partnerships between Indigenous and non-Indigenous couples, and changing procedures for estimating Indigenous population numbers (see Taylor, 2013 for more details). The issue is of significant importance for the financial capacity of northern Australia because it affects the distribution of approximately $\$ 40$ billion in GST revenues to the States and Territories and, consequently, the capacity for individual governments to address Indigenous outcomes in northern jurisdictions. The Northern Territory Government has already seen its GST revenues fall by $4 \%$ as a result and, while re-negotiations on processes for distributing the GST are currently in the political spotlight (for example, Australian Broadcasting Corporation, 2015) the issue of Indigenous disadvantage as it translates to financial needs and distributions for individual States and Territories is extremely complex and under-researched. Moreover, arguments over GST distributions are overtly made along geographic and party political lines, negating a system and region-wide approach to understanding and addressing the issue; a necessary but unmentioned topic in the Developing Northern Australia policy context.

On the whole, the demography of developing northern Australia features a range of population and settlement characteristics which are highly related to past pathways for economic development and the role of the north in national agendas (for example, as strategically important militarily). These present a range of challenges including a growing male bias and a reduced focus on regions outside of urban zones. Nevertheless, opportunities do exist in relation to the Developing Northern Australia policy. An increasing focus on international migrants and nonresident workers creates opportunities around education and tourism related services. Numbers of intergenerational families are growing, helping to balance out the heavy losses of residents in 


\section{CHABES Northern

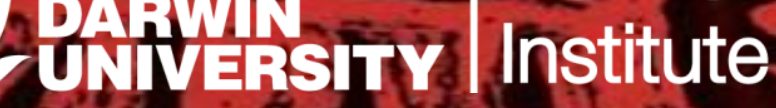

pre and early retirement ages and by providing social and financial capital to communities, in spite of population ageing. To achieve the targets provided in the White Paper will require a very 'big Australia' and it is interesting the Government has chosen to incorporate such targets, which can best be described as aspirational, given backlash over the previous Australian Government's policy in support of a 'big Australia'. Meanwhile, population ageing in the north, combined with the declining Indigenous share compared to southern Australia, both represent immediate and long term threats to the finances of the region, and in turn the capacity for addressing resident's needs in terms of services and infrastructure. Both are sufficiently influential to warrant a region-wide research agenda including work to project future population sizes and compositions under a range of development scenarios. 


\section{Finagres Northerm

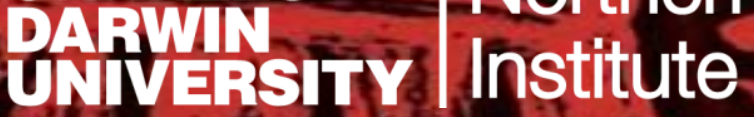

\section{References}

ABS (2014) 3105.0.65.001 - Australian Historical Population Statistics, 2014. Accessed 20 June 2015 from http://www.abs.gov.au/ausstats/abs@.nsf/mf/3105.0.65.001

ABS (2015). 3101.0 - Australian Demographic Statistics, December 2014. Accessed 14 April 2015 from http://www.abs.gov.au/ausstats/abs@.nsf/mf/3101.0

Australian Broadcasting Corporation (2015). COAG: Talks end with no resolution over GST stoush, Colin Barnett describes meeting as 'disappointing'. Accessed 20 April, 2015 from http://www.abc.net.au/news/2015-04-17/coagmeeting-ends-with-no-resolution-to-gst-carve-up/6400968

Australian Government (2014a). Green Paper on Developing Northern Australia. Accessed 16 July 2014 from http://northernaustralia.dpmc.gov.au/sites/default/files/papers/green_paper.pdf

Australian Government (2014b). Pivot North - Inquiry into the Development of Northern Australia: Final Report. Canberra: Australian Government.

Australian Government (2015). Our North, Our Future: White Paper on Developing Northern Australia. Accessed 4 July 2015 from https://northernaustralia.dpmc.gov.au/white-paper

Carson, D. \& Schmallegger (2009). Why don't women like Darwin? Accessed 20 April 2015 from http://www.cdu.edu.au/sites/default/files/research-brief-2009-36.pdf

Carson, D., Ensign, P., Rasmussen, R.O. \& Taylor, A. (2011). Perspectives on 'Demography at the Edge', In D. Carson, R. Rasmussen, P. C. Ensign, A. Taylor and L. Huskey (Eds). Demography at the Edge: Remote human populations in developed nations (pp. 3-20). Farnham, England: Ashgate Publishing.

Carson, D. (2011a) Population Policies at the Edge: The demographic ambitions of frontiers. In D. Carson, R. Rasmussen, P. C. Ensign, A. Taylor and L. Huskey (Eds). Demography at the Edge: Remote human populations in developed nations (pp. 321-332). Farnham, England: Ashgate Publishing.

Carson D. (2011b). Political economy, demography and development in Australia's Northern Territory. Canadian Geographer, 55(2), 226-242.

Carson, D. \& Taylor, A. (2012). The Northern Territory's Non-Resident Workforce. Accessed 2 December 2014 from http://www.cdu.edu.au/sites/default/files/research-brief-2012-04.pdf

Coombs, H. (1947) Development of Northern Australia. Report of the Northern Australian Development Committee, Canberra.

Cunningham, T. \& Beneforti, M. (2008). NT Mobility Project: Movers out of the Northern Territory. Accessed 13 April 2015 from http://www.cdu.edu.au/sites/default/files/research-brief-2008-14.pdf

Department of Immigration and Border Protection (2014). Migration to Australia's states and territories 2012-13. Canberra: Australian Government.

Harris, P. (1992) A Strategy for Promoting the Economic Growth of Northern Australia, Report to the Commonwealth Government. Townsville: Centre for Applied Economic Research and Analysis, JCU.

Liberal Party of Australia (2013). The Coalition's 2030 Vision for Developing Northern Australia. Accessed 4 February 2015 from http://lpaweb-tatic.s3.amazonaws.com/Policies/NorthernAustralia.pdf

Payer, H. \& Taylor, A. (2015). Northern Territory seats in the Australian Parliament: It's a long way up, but not far down. Accessed 1 April 2015 from http://www.cdu.edu.au/northern-institute/ni-research-briefs

Taylor, A., Larson, S., Stoeckl, N. \& Carson, D. (2011). The haves and have nots in Australia's Tropical north - new perspectives on a persisting problem. Geographic Research, 49(1), 13-22. 


\section{CHABES Northern - U. UESTYI Institute}

Taylor, A. (2013). The Northern Territory's Declining Share of Australia's Indigenous Population: A call for a research agenda. Accessed 20 April 2015 from http://www.cdu.edu.au/sites/default/files/research-brief-2013-2.pdf

Taylor, A. \& Bell, L. (2013). The Northern Territory's declining share of Australia's Indigenous population: A call for a research agenda. Accessed 14 April 2015 from http://www.cdu.edu.au/sites/default/files/research-brief-2013$\underline{\text { 2.pdf }}$

Taylor, A. \& Carson, D. B. (2014). It's raining men in Darwin: Gendered effects from the construction of major oil and gas projects. Journal of Rural and Community Development, 9(1), 24-40.

Winther, G. (Ed) (2010). The Political Economy of Northern Regional Development: Vol. I. Copenhagen: Nordic Council of Ministers, Copenhagen.

Zeng, B., Brokensha, H. \& Taylor, A. (2015). Now You See Us! A Report on the policy and economic impacts from rapid growth in the number of senior Territorians. Darwin: Northern Institute, Charles Darwin University. 